\title{
Journeying to freedom: the spatial ecology of a reintroduced population of Orinoco crocodiles (Crocodylus intermedius) in Colombia
}

Rafael A. Moreno-Arias ${ }^{1,2^{*}}$ and María Cristina Ardila-Robayo ${ }^{2 \wedge}$

\begin{abstract}
Background: The Orinoco crocodile (Crocodylus intermedius) is the largest crocodile and the most threatened by extinction in the Neotropics due to overexploitation for the skin trade during the early-middle twentieth century. Knowledge of their ecology is poor in Colombia because long-term armed conflict has restricted fieldwork. In 2015, we reintroduced four captive-reared adult crocodiles, each equipped with a Sirtrack KiwiSat 202 satellite transmitter and monitored their movements from 2015 to 2018.

Results: Seasonal movements were as far $177 \mathrm{~km}$ in males and $115 \mathrm{~km}$ in females. Home ranges were as large as $55 \mathrm{~km}^{2}$ for males and $16 \mathrm{~km}^{2}$ for females for a single year and $178 \mathrm{~km}^{2}$ and $21 \mathrm{~km}^{2}$, respectively, for males and females over 2 years. Spatial ecological patterns changed drastically by season, with males increasing their home range and females reducing home range during the wet season. We confirmed that daily activity patterns defined as measure by number of locations across the day were not influenced by season.

Conclusions: We believe that seasonal changes in the size and shape of home ranges were associated with patrolling or exploratory behaviors after release, while daily activity behavior was independent of season, sex or size of the animal.
\end{abstract}

Keywords: Crocodylus intermedius, Home range, Movements, Activity, Guayabero-Losada River basin

\section{Background}

The Orinoco crocodile (Crocodylus intermedius) is the largest crocodile in the Neotropics [1] and is currently classified by the IUCN as Critically Endangered [2]. There are less than 250 adult crocodiles remaining within their small and severely fragmented range that extends from Venezuela to Colombia [3]. With a decrease in armed conflict, new data indicate that crocodile populations are not recovering and even suggest that local extinctions may have occurred $[4,5]$.

\footnotetext{
*Correspondence: rafamorearias@gmail.com

${ }^{1}$ Dirección de investigaciones, Corporación Universitaria del Meta, Villavicencio, Colombia

Full list of author information is available at the end of the article Deceased: María Cristina Ardila-Robayo
}

The ecology of the Orinoco crocodile is also poorly known, with most studies focused on captive individuals or from population concentrated in a few localities in Venezuela [6]. Spatial ecology information is particularly scarce and represented by anecdotical data [1], long-term movements of juvenile crocodiles [7] or short-term preliminary information on adults [8].

Telemetry tracking has been utilized for monitoring the survival of released crocodiles [9] and is an effective method for studying several features of the spatial ecology of crocodilians such as home range, movement patterns, identification of nesting sites and activity patterns [10-13]. Understanding the spatial ecology of reintroduced species can provide relevant information for their successful reintroduction [14], for example to determine the territoriality or overlap degree of home range for 
jaguars reintroduction [15] or to detect areas of which conservation effort should be implanted in reintroduced population of Canadian lynx [16].

To ameliorate the risk of extinction, conservation actions in Colombia have focused on reproduction in captivity and reintroduction of captive-reared crocodiles [17]. Captive rearing was first begun in the $1970 \mathrm{~s}$ but reintroduction has only recently been attempted $[8,18]$. Due to longstanding armed conflict in Colombia, evaluating the effect of reintroduction has been impractical, and the only information on the ecology and natural history of the species has been obtained during rapid censuses [19-22].

To understand the spatial ecology of reintroduced Orinoco crocodiles, we deployed satellite transmitters to captive-reared Orinoco crocodiles and monitored movements of those animals for up to 2 years.

\section{Results}

We tracked 4 captive-reared Orinoco crocodiles for up to 26 months after release. Fem_G was tracked for 26 months (November 2015-December 2017), Male_G was tracked for 21 months (November 2015-July 2017), Fem_L was tracked for 17 months (November 2015March 2017), and Male_L was tracked for 11 months (November 2015-September 2016). We obtained a total of 4142 locations with $25 \%$ as LC3, $18 \%$ as LC2, $13 \%$ as $\mathrm{LC} 1,4 \% \mathrm{LC} 0$, the remaining $40 \%$ represented LCB, LCA and no location. For Fem_G and Male_G, we obtained 1457 and 1079 locations, respectively, and for Fem_L, 1070 locations were obtained, and for Male_L, only 536 locations were obtained. For all crocodiles, the distribution of locations by accuracy classes was similar with LC3 and LCB being the more frequent locations (Table 1).

\section{Movements}

The longest tracking distance (TD) was achieved by Male_L, which travelled $270 \mathrm{~km}$ in 11 months, followed by Fem_L with $362 \mathrm{~km}$ in 17 months, Fem_G with $318 \mathrm{~km}$ in 26 months and Male_G with $246 \mathrm{~km}$ in 21 months (Fig. 1). The farthest linear distance from the release site was also achieved by Male_L with $64 \mathrm{~km}$, followed by Male_G with $22 \mathrm{~km}$, Fem_L with $16 \mathrm{~km}$ and Fem_G with just $9.8 \mathrm{~km}$. We found a strong positive correlation between age and release distance (RD) $\left(r_{\text {Spearman }}=0.81, p=0.0005, N=14\right)$ and a weak positive correlation between activity per day $\left(r_{\text {Spearman }}=0.54\right.$, $p=0.045, N=14$ ).

The mean step length (MST) was longest in the smallest crocodiles (Fem_L and Male_L: 0.5 and $0.8 \mathrm{~km}$, respectively) than biggest ones (Fem_G and Male_G: $0.4 \mathrm{~km}$ ) and nearly similar between sexes (females: $0.5 \mathrm{~km}$, males $0.6 \mathrm{~km})$. Across season the MST of crocodiles were short during dry 2015-2016 (0.3 km) and long in wet 2016, in both remain seasons the MST was of $0.5 \mathrm{~km}$. Largest MST in males was exhibited by Male_L in wet 2016 $(1.0 \mathrm{~km})$ and the shortest MST by Male_G $(0.1 \mathrm{~km})$ in dry 2015-2016. Largest and shortest female MST was exhibited by Fem_G in dry 2017-2018 (0.7 km) and wet 2016 $(0.2 \mathrm{~km})$, respectively. MST was stronger correlated with TD $\left(r_{\text {Spearman }}=0.83, p=0.0001, N=14\right)$ than RD $\left(r_{\text {Spear- }}\right.$ $\operatorname{man}=0.68, p=0.004, N=14)$.

Across the 2015/2016 dry season, crocodiles from the Losada River travelled longer distances and moved further away from their release location than the Guayabero crocodiles (Fig. 1). In the 2016 wet season, Losada's crocodiles travelled more and moved farther away than the Guayabero's crocs. Fem_G remained near the release site despite the long distances travelled and the shortest RD (Fig. 1). During the 2016/2017 dry season the crocodiles from Guayabero river exhibited a longer TD than Losada's female (Fig. 1). In wet 2017, Fem_G travelled more distance but stayed closer of release site than Male_G (Fig. 1).

Several changes in movement patterns arose between the dry and wet seasons. From 2015/2016 dry to 2016 wet season, all crocodiles increased their release distance (88-890\%), with the exception of Fem_G which got closer to her release site (Fig. 1). These seasonal changes in RD were correlated with sex only in the former pair $\left(X^{2}=63.3, p=0.0001\right)$ and they were mostly associated with an increase of step length (Fig. 1). From the 2016 wet to the 2016/2017 dry season the crocodiles increased their RD (1-342\%). These seasonal changes in RD were correlated with sex $\left(X^{2}=5.0, p=0.006\right)$, and they were

Table 1 Percentage of locations by Argos accuracy class of Orinoco crocodiles tracked during 2015-2018 climatic seasons in the Guayabero and Losada Rivers

\begin{tabular}{|c|c|c|c|c|c|c|}
\hline Crocodile & LC3 & $\mathrm{LC} 2$ & LC1 & LCO & LCB & LCA \\
\hline Fem_G & 25.1 & 17.5 & 12.8 & 4.0 & 29.1 & 11.6 \\
\hline Male_G & 24.8 & 17.5 & 13.6 & 4.8 & 26.5 & 12.7 \\
\hline Fem_L & 27.5 & 18.6 & 14.7 & 4.6 & 23.2 & 11.5 \\
\hline Male_L & 23.5 & 16.6 & 10.8 & 3.5 & 28.5 & 17.0 \\
\hline
\end{tabular}




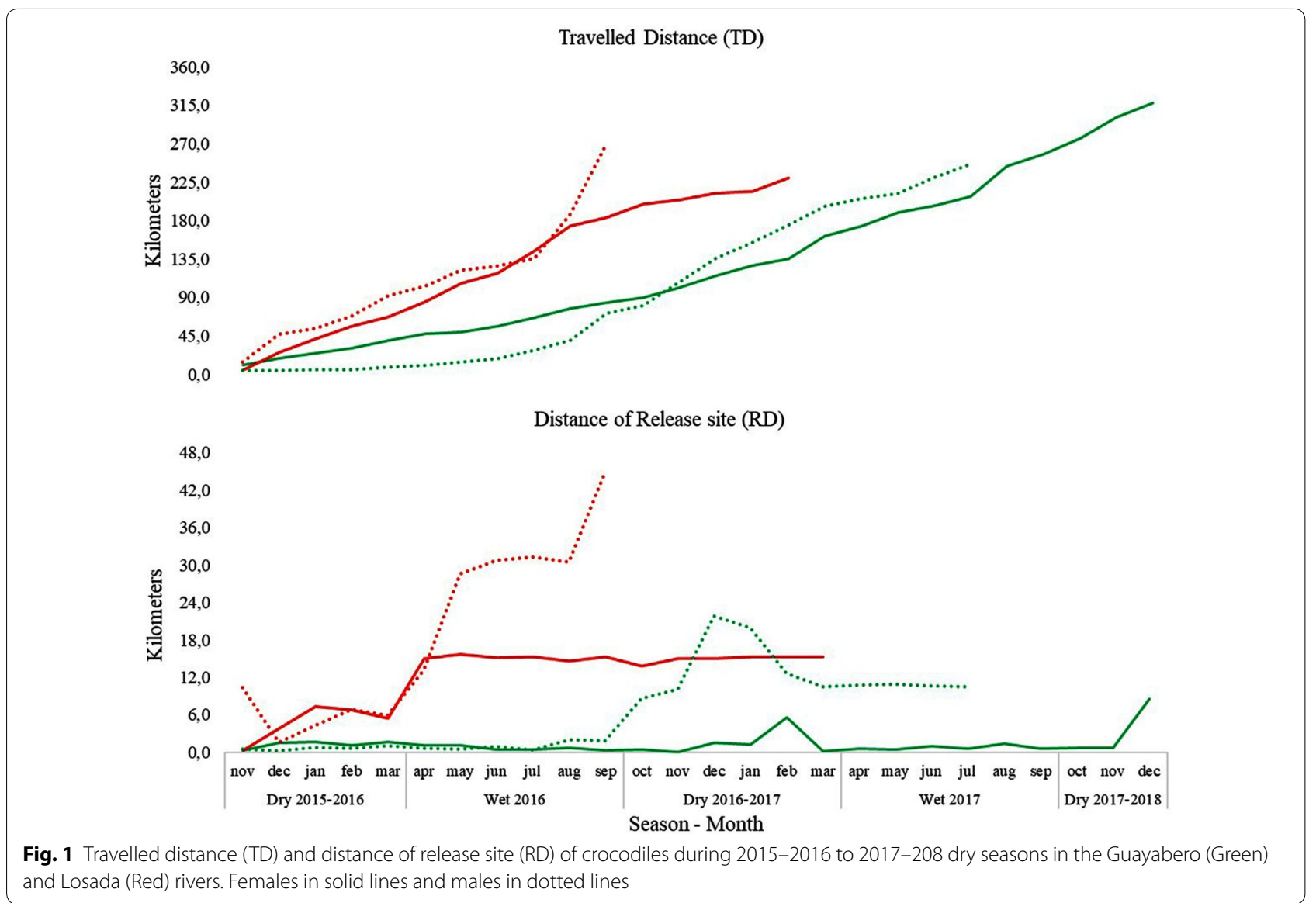

also mostly associated with an increase of step length but a decrease of its frequency (Fig. 1). From the 2016/2017 dry to 2017 wet season, the changes in RD were associated with $\operatorname{sex}\left(X^{2}=8.1, p=0.006\right.$, respectively), increasing in females $(17 \%)$ and decreasing in males $(-7 \%)$. These RD female and male changes also related, respectively, to a decreasing $(-2 \%)$ and an increasing $(14 \%)$ in step length.

\section{Home range}

The largest total home range was achieved by Male_L $\left(85 \mathrm{~km}^{2}\right)$, followed by Male_G $\left(57.6 \mathrm{~km}^{2}\right)$, Fem_L $\left(21.3 \mathrm{~km}^{2}\right)$ and Fem_G $\left(20.2 \mathrm{~km}^{2}\right)$. The trend in the core area was similar to the home range; males exhibited larger areas (Male_G: $85 \mathrm{~km}^{2}$, Male_L: $10.4 \mathrm{~km}^{2}$ ) than females (Fem_L: $3.8 \mathrm{~km}^{2}$, Fem_G: $2.2 \mathrm{~km}^{2}$ ).

Across the 2015/2016 dry season, Losada's crocodile home range and core area values were larger than those of the Guayabero (Table 2). In the 2016 wet season, the pattern of home ranges and core areas changed slightly: Males exhibited larger areas than females (Table 2).
Table 2 Home range and (core area) estimates of Orinoco crocodiles tracked during 2015-2018 climatic seasons in the Guayabero and Losada Rivers

\begin{tabular}{llc}
\hline Season & Crocodile & $\begin{array}{c}\text { KHER 95\% } \\
\mathbf{( 5 0 \% )} \mathbf{~ K m}^{\mathbf{2}}\end{array}$ \\
\hline Dry 2015/2016 & Fem_G & $5.0(0.9)$ \\
& Fem_L & $16.2(3)$ \\
& Male_G & $3.0(0.8)$ \\
Wet 2016 & Male_L & $31.8(4.5)$ \\
& Fem_G & $4.4(0.8)$ \\
& Fem_L & $5.0(0.7)$ \\
Dry 2016/2017 & Male_G & $6.9(1.3)$ \\
& Male_L & $55.3(4.6)$ \\
Wet 2017 & Fem_G & $15.6(1.8)$ \\
Dry 2017/2018 & Fem_L & $3.2(0.6)$ \\
& Male_G & $48.9(8.3)$ \\
& Fem_G & $12.6(1.3)$ \\
& Male_G & $9.1(1.3)$ \\
& Fem_G & $4.5(0.7)$ \\
\hline
\end{tabular}


During the 2016/2017 dry season, Guayabero's crocodiles exhibited the largest home ranges and core areas (Table 2), and during the 2017 wet season, Fem_G exhibited a larger home range and core area than Male_G (Table 2).

Crocodiles drastically changed the size and shape of their home ranges and core areas throughout the seasons. From 2015/2016 dry to 2016 wet season (Table 2, Fig. 2), males increased their home ranges (74-130\%, Losada and Guayabero, respectively) and their core areas (2-63\%, Losada and Guayabero, respectively). In contrast to the males, females exhibited moderate decreases in both home ranges $(-69 \%$ and $-12 \%$ Losada and Guayabero, respectively) and core areas $(-77 \%$ and $-11 \%$, Losada and Guayabero, respectively). Seasonal changes in home range and core area size were significantly different between sexes in both pairs of crocodiles: Guayabero $\left(X^{2}=10.9, p=0.0011\right.$ and $X^{2}=4.5, p=0.04$, respectively) and Losada $\left(X^{2}: 48.1, p=0.0001\right.$ and $X^{2}: 22.5$, $p=0.001$, respectively).

The shape of Male_G's home range from 2015/2016 dry to 2016 wet (Fig. 2) changed from a uniquely contiguous area to seven areas (one large and six small), whereas the Male_L changed from eight noncontiguous areas (four large and four small) to 11 (two large and nine small). Fem_G's home range shape changed slightly from four noncontiguous areas (one large and three small) to two (one large and one small), whereas Fem_L changed its home range from four noncontiguous areas (two large and two small) to eight (one large and seven small).

During the 2016/2017 dry season (Fig. 3) females greatly increased their home ranges $(878 \%$ and $255 \%$, Losada and Guayabero, respectively) and core areas (1086\% and 125\%, Losada and Guayabero, respectively). In contrast, males exhibited a moderate decrease of $54 \%$ of their home range and core area sizes. Changes in home range and core areas were significantly different between the sexes $\left(X^{2}=42.7, p=0.0001\right.$ and $X^{2}=27.4$, $p=0.04$, respectively). With relation to home range shape changes, Male_G changed its home range shape in five areas (one very large and four small), Fem_G to four areas (one large and three small), and Fem_L changed it to only one large area (Fig. 3).

During the 2017 wet season crocodiles decreased their home ranges $(-42 \%$ and $-74 \%$, female and male, respectively) and core areas $(-28 \%$ and $-46 \%$, female and male, respectively) according to their sex (home range: $X^{2}=38.1, p=0.0001$ and core area: $X^{2}=13.7$, $p=0.0004)$. Home range shape also changed: Male_G exhibited a one area home range while Fem_G increased it to six areas (one large and five small areas) (Fig. 3). By the 2017/2018 dry season (Fig. 3), Fem_G had decreased her home range $(-51 \%)$ and its core area $(-46 \%)$; and reduced her home range to three areas (a very large and two very small areas) (Fig. 4).

\section{Activity}

Activities were different among the crocodiles across seasons $(H=40.4, p=0.0001, \mathrm{~d} f=13)$, between sexes across seasons $(H=17.2, p=0.01, \mathrm{~d} f=7)$ and between pairs of crocodiles $(H=17.2, p=0.01, \mathrm{~d} f=7)$ (Fig. 5). Females and the smallest crocodiles (released on Losada River) were more active on average than were the males during the first year after release; after this, the activity of Male_G was slightly higher than that of the females (Fig. 5).

Daily activities did not differ among crocodiles $\left(X^{2}\right.$ : $1.19, p=0.98)$ and sexes $\left(X^{2}: 0.53, p=0.98\right)$, but they differed among time intervals $\left(X^{2}: 8.34, p=0.04, \mathrm{~d} f=3\right)$. Crocodiles were more active in the morning than in the evening $(p=0.02)$ or noon $(p=0.003)$. This result indicated that daily activity was not uniform, despite crocodiles being active throughout the day, they increase by $8 \%$ their activity in the morning and the early morning (Fig. 6).

\section{Discussion}

We deployed satellite transmitters to four reintroduced (captive reared) Orinoco crocodiles (Crocodylus intermedius). Our results represent the longest period of satellite telemetry monitoring for this species and despite the small sample size, some trends in movement patterns and habitat use are apparent.

Crocodiles drastically changed their spatial use and movement patterns between the wet and dry seasons. In general, crocodiles travelled more in the wet season compared to the dry season; and males move farther from their release location than females. The smallest crocodiles and male crocodiles had larger home ranges and high use areas than the largest female crocodiles. Males exhibited larger home ranges during the wet season, and females exhibited their largest home ranges during the dry season. Daily activity patterns (as measure by number of locations) were the same regardless of season, body size or age: all were more active during two peaks, early morning to morning and late afternoon to evening.

Despite the maximum distance travelled during a season (177 km in males and $115 \mathrm{~km}$ in females) is nearly twice less than the largest travel registers by saltwater crocodile during a climatic season [23, 24], it indicates that at least adult individuals of Orinoco crocodile can be notorious voyagers also. Dispersal distances varied, with the Guayabero pair staying within $1 \mathrm{~km}$ of its release site, and the other pair moving $7 \mathrm{~km}$ away during the first 3 months. This result contrasts with the dispersal of captive-reared juvenile who dispersed around 3 to $4 \mathrm{~km}$ 3 months after its release [25]. The dispersal patterns in 


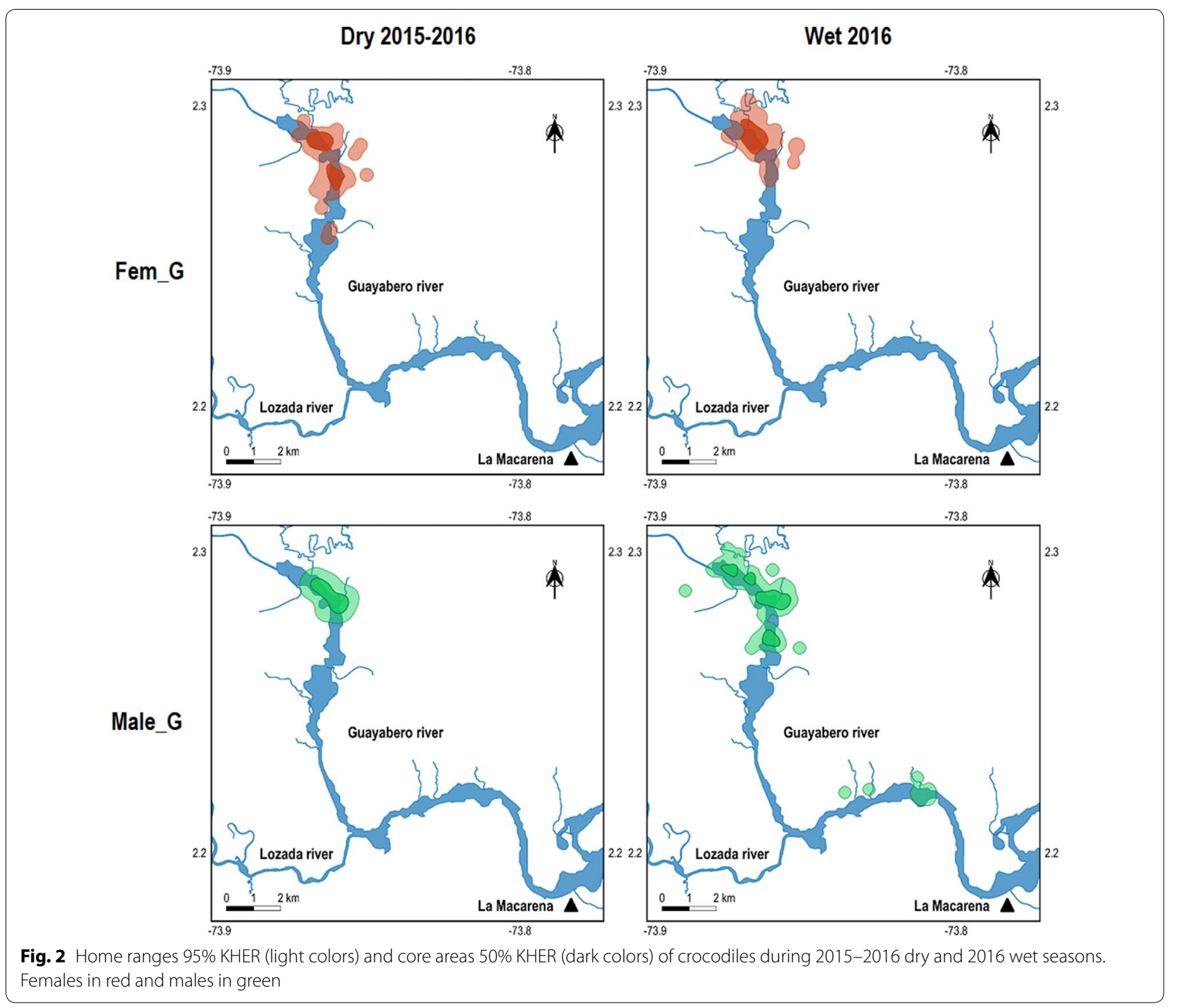

this study also showed marked contrast to others as these animals dispersed from release location in small incremental movements, in contrast to other studies that indicate rapid direct movements around 6 to $9.9 \mathrm{~km}$ away from their release location in the first 2 months [7].

We did not detect strong evidence that changes in home ranges and core areas were related to the movement estimators travelled or release distance, which reinforces that the relationship between movement and home range is not always direct in crocodiles, as previously documented in C. acutus, for which subadults showed longest average movement distance than juvenile but their home ranges were very similar, or for similar average movements distance between subadults and adults, but a home range twice as large as in the former [10]. We observed two main behaviors in crocodile movement and habitat use in response to reintroduction as well as its role in the population (with respect to its sex and size) during each season. One pattern consisted of relatively long steps across small home ranges within a contiguous area habitat. The second pattern consisted of short steps across large home ranges within several noncontiguous areas. We characterize such behavior as those of a patroller and those of an explorer, when movement is restricted to a large particular area which is covered by systematic long trips (patrolling) or when the movement 


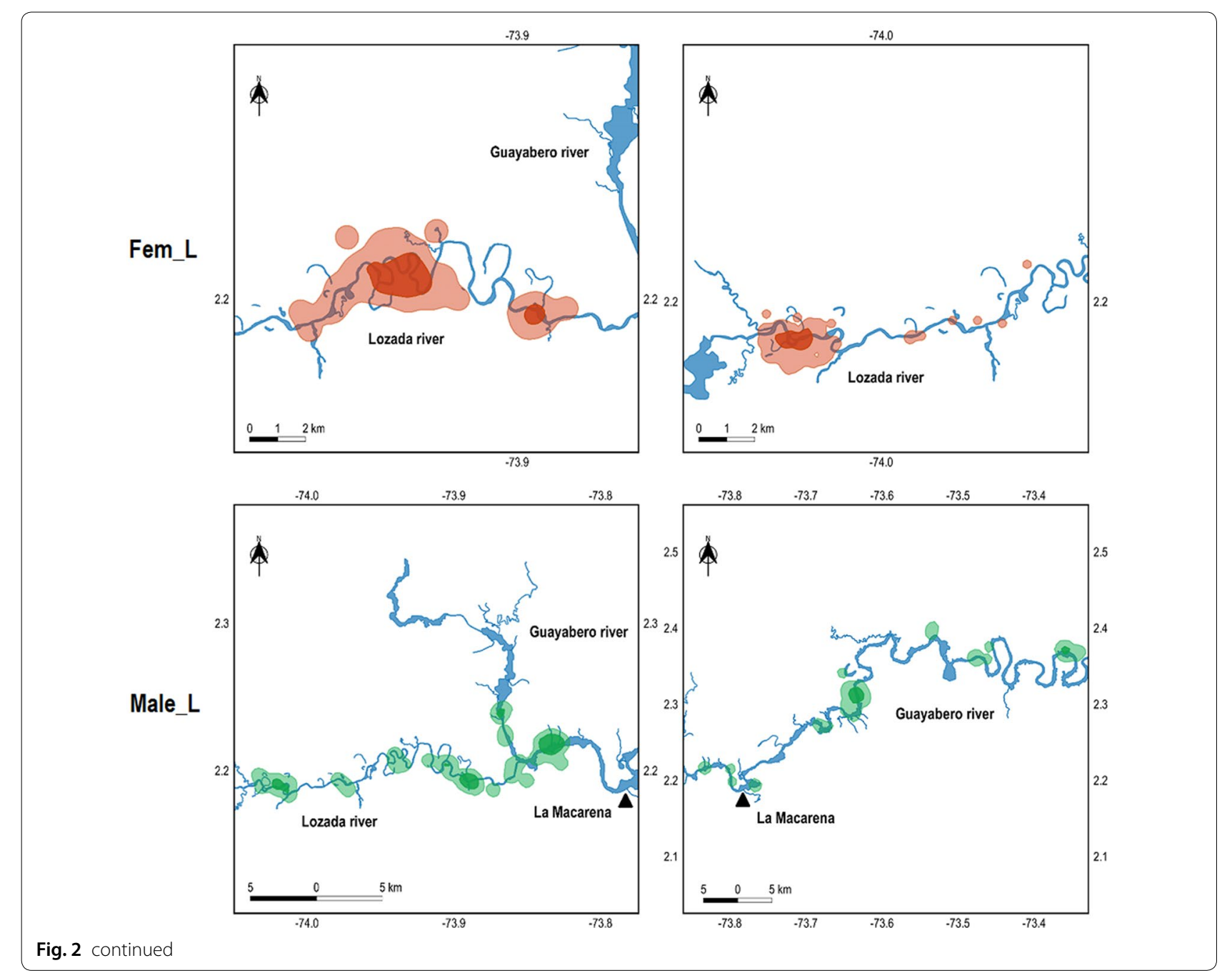

is restricted to several intermediate-size areas which are covered by a like "stepping stone" short steps to discover new areas (exploring).

It is known that after release, the smallest crocodiles needed to disperse during the months to take possession of a territory (for nesting in females) or to explore for a year without finding a territory to settle in young males [26]. Disperse behavior of our smallest male, Male_L, could be an example of the typical young crocodiles seeking for territory, however, this behavior must with more data from other reintroduced crocodiles. The largest crocodiles settled in a territory around their release site, which suggested that large Orinoco crocodiles (in our case males $>3.1 \mathrm{~m}$, females $>2.4 \mathrm{~m}$ ) are able to defend a territory from at least the first year after release in sites where large adults are already known to live. After release and with territories already established, crocodiles showed both explorer and patroller seasonal behaviors, according to their roles in the life-cycle.

Different movements between seasons seem to be a ubiquitous pattern among crocodilians as a result of dynamic resource availability or ontogenetic niche requirements [27, 28]. Kernohan et al. [29] reported that the seasonality of male movements may indicate dynamic interactions between males as they seek or defend territories [27]. Agonistic interactions also occur between females when an intruder enters an occupied territory [1], but females also travel during the late breeding season to find the best beaches for nesting, which usually occurs during the dry season $[27,30-32]$ and so their seasonal movements are different from males. The Orinoco crocodile appears to follow this same pattern, with its life-cycle being closely associated with seasonal water dynamics in a way that is very similar to that of the American crocodile [10]. 


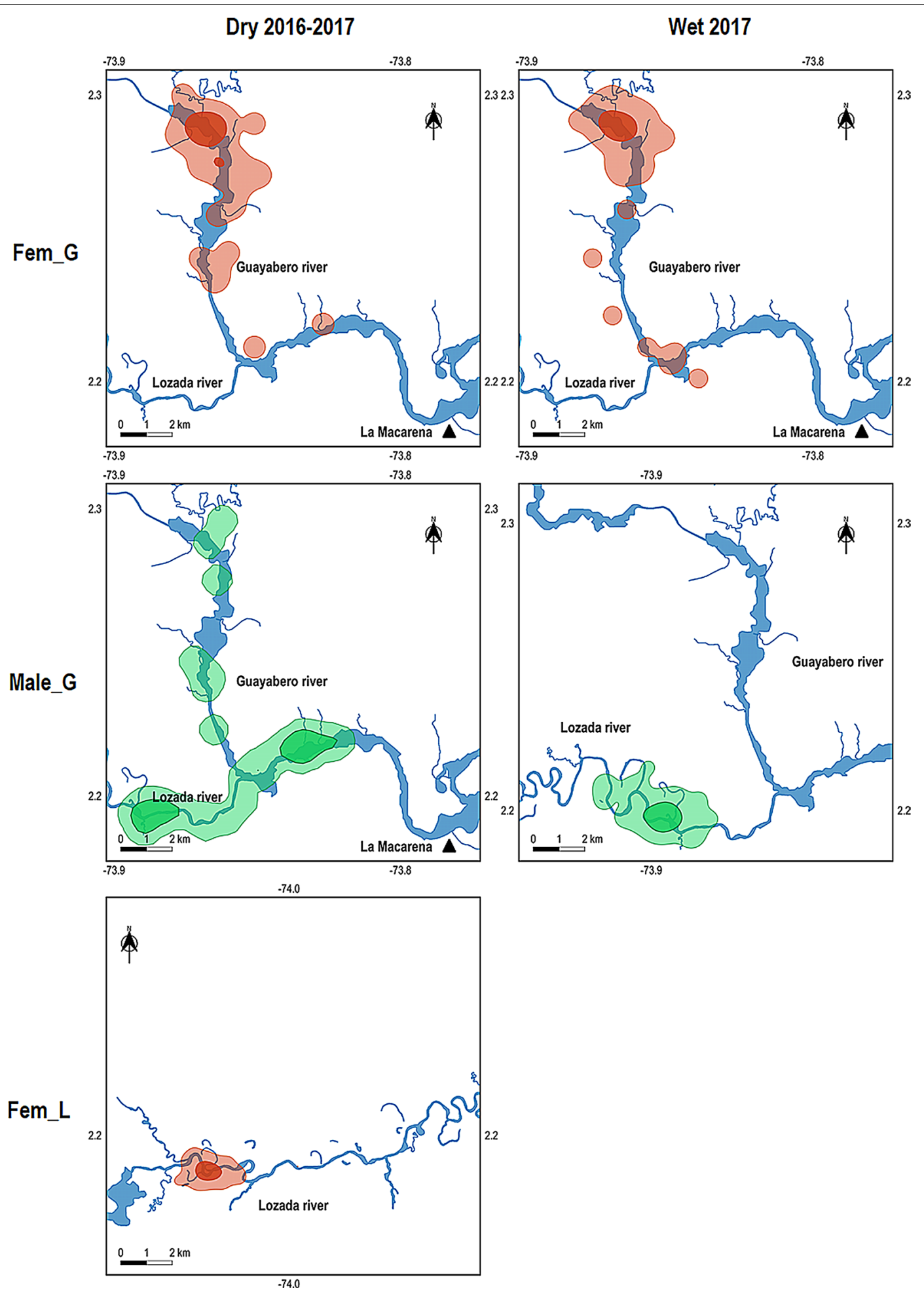

Fig. 3 Home ranges 95\% KHER (light colors) and core areas 50\% KHER (dark colors) of crocodiles during 2016-2017 dry season and 2017 wet season. Females in red and males in green 


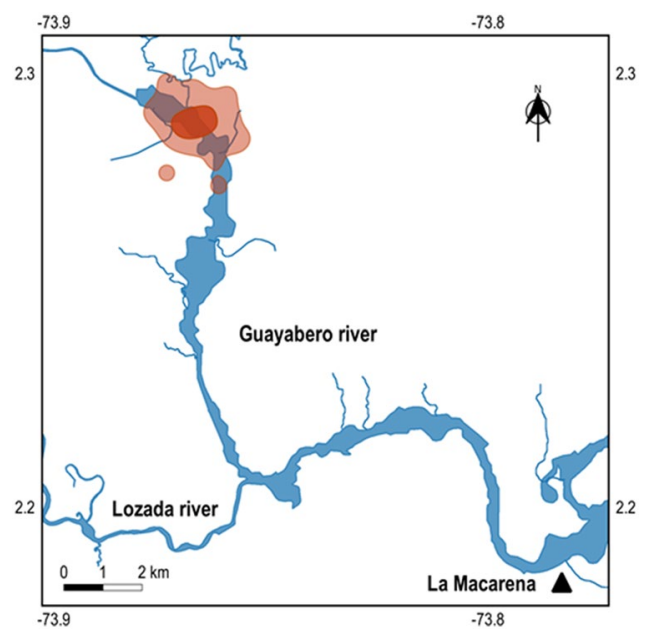

Fig. 4 Home range 95\% KHER (light colors) and core area 50\% KHER (dark colors) during the 2017-2018 seasons of Fem_G

During the mid-to-late wet season, courtship and mating occur; during the dry season, nesting occurs; and during the late-dry and early-wet season, hatching occurs [1].

The roles of adult crocodiles are different for each life-cycle phase based on their different movement patterns. In the 2016 wet season, male movements were high and it could be related with the seeking for mates as well as defending territories, as previously registered for the species during wet seasons [1]. This relates to the explorer behavior that extended to the 2016-2017 dry reproductive season. It has been reported for the Orinoco crocodile and other crocodilians species that in the dry season females seek nesting beaches [26, 31, 32]. During the 2016-2017 and 2017-2018 dry seasons, the largest female was exploring and moved away from its released site; a possibility is those movements could indicate trips where new nesting beaches discovered were unsuccessful, and it is mainly supported by the fact that the core area always remains at the release site.

It is interesting that crocodiles from Guayabero River have overlapped its home range during dry 2016-2017 in the area at the confluence of the Guayabero and Losada Rivers, where one of the best nesting beaches occurs (R.M.A. Pers. Obs. 2016), because this area could be an important site to both study and monitor the reproductive ecology of species.

In wet 2016 both males increased their home ranges nearly twice compared with the previous dry season, this increase could be associated to exploring the surrounding floodplain in rainy season (including oxbow lakes reconnected with the main river), which is a behavior previously documented in the Orinoco crocodiles $[6,25,33]$. However, our results partially matched with the mentioned behavior because in posterior seasons the change of home range size for Male_G was inverse: a smaller home range in wet 2017 than 20162017 dry season. Changes in size and shape of size of home range observed for Male_G during dry 20162017 to wet 2017 indicated a change of territory that could be product of the expulsion of its previous territory by a larger male. A similar behavior was already documented in saltwater crocodile from Australia and was associated to site-fidelic male patrolling around female territory and to subordinated nomadic males which were forced to travel long distances for search of unguarded females [12].

Even with the difficulty of comparing home range estimates of several species in diverse habitats using with different methods, or as our case of a very small sample

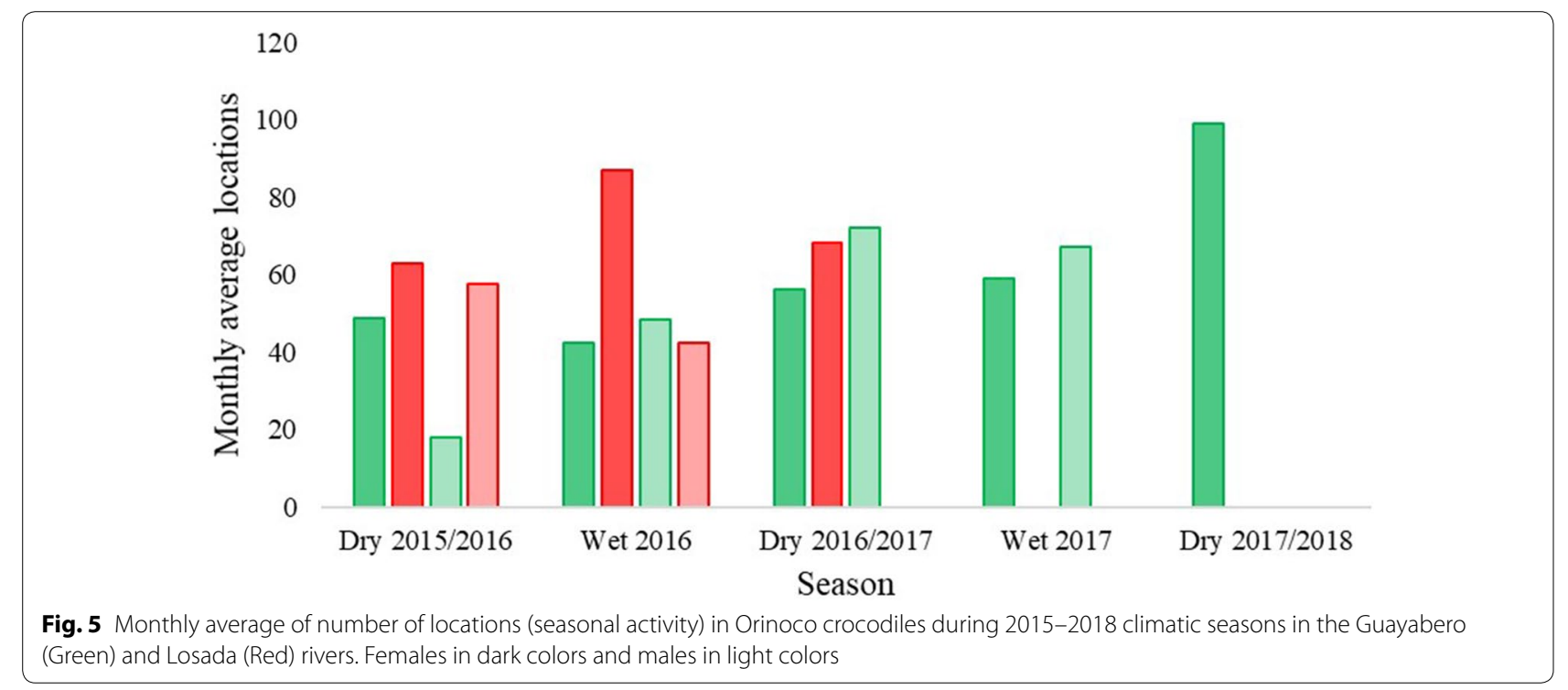




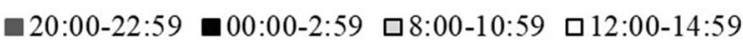

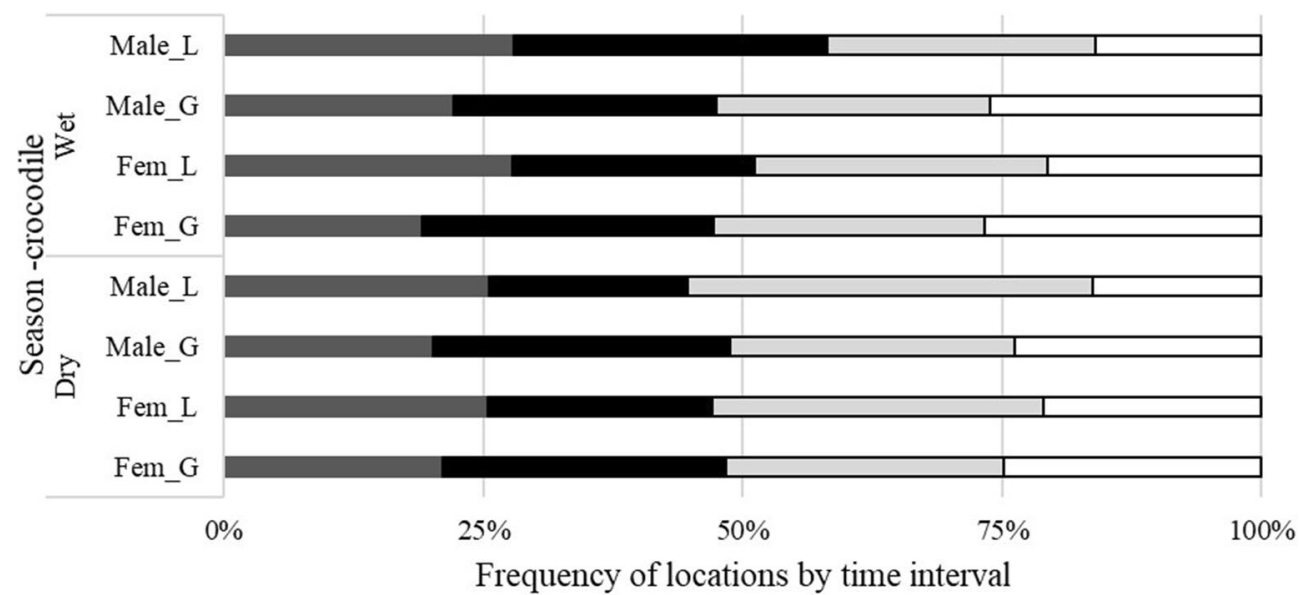

Fig. 6 Distribution of locations across the day (daily activity) between seasons of Orinoco crocodiles during the 2015-2018 seasons in the Guayabero and Losada Rivers

size, we can state that the maximum home ranges by season for Orinoco crocodile (48 and $55 \mathrm{~km}^{2}$ for males and 15 and $16 \mathrm{~km}^{2}$ for females) represent one of the largest documented for crocodilians. Compared with C. porosus [27], males of C. intermedius possess similar home ranges, but females possess home ranges up to six times larger. Males of the Orinoco crocodile have home ranges approximately four times larger and females approximately three times larger than those of C. acutus [10] and five and approximately 12 times larger than C. niloticus [34]. Both male and female Orinoco crocodiles have home ranges two and six times larger than those of Alligator mississippiensis [11].

Daily activity patterns of Orinoco crocodiles seem to partially match other studies and reflect two daily highactivity periods, during morning and afternoon, when crocodiles are fishing, hunting or basking [6]. It has been suggested that land hunting by crocodiles occurs in the early morning [20] and while our data support this idea we also believe that they are also active hunters late at night in at least the Guayabero River (R.M.A. Pers. Obs. 2016). It has been documented that the Orinoco crocodile exhibited only one period of activity from morning until afternoon in the wet season [6]; however, we observed the same bimodal pattern of activity in both wet and dry seasons. This bimodal daily pattern has also been attributed to thermoregulatory behavior in several crocodilian species [35-38].

Despite the data presented here are represented by only four individuals, these highlight the reliability of reintroducing adult crocodiles and monitoring them successfully through telemetry approaches. A relatively yearly-constant territory and low dispersal for females indicates that supplementation with large females could be a key tool for conservation because it permits the implementation of management actions under a spatialtemporal limit below $16 \mathrm{Km}^{2}$ during the first 2 years after reintroduction per female. The supplementation with large males could be more restrictive, and it should be made with crocodiles larger than males already in populations, to avoid changes in territories and large dispersal of reintroduced crocodiles which would hinder the implementation of management action under a spatial and temporal framework. However, if that requirement is accomplished, it would define the same approach of females.

\section{Conclusions}

We propose that seasonal changes in size and shape of home ranges are associated with the patroller or exploratory behavior. Our smallest crocodiles exhibited explorer behavior after release which translated into large home ranges composed of several small noncontiguous areas, whereas the larger crocodiles exhibited what we define as patroller behavior consisting of home ranges defined by only one mid-sized area. Patroller behavior was mainly exhibited by males during the dry season-possibly to defend resources and by females during the late-dry to early-wet season possibly related to nesting protection and parental care. Explorer behavior was common in males in the late wet season possibly to find and fight for mates, and to females in the dry season as a possible response to the need to find nesting sites. Crocodile activity periods were consistent across seasons. 


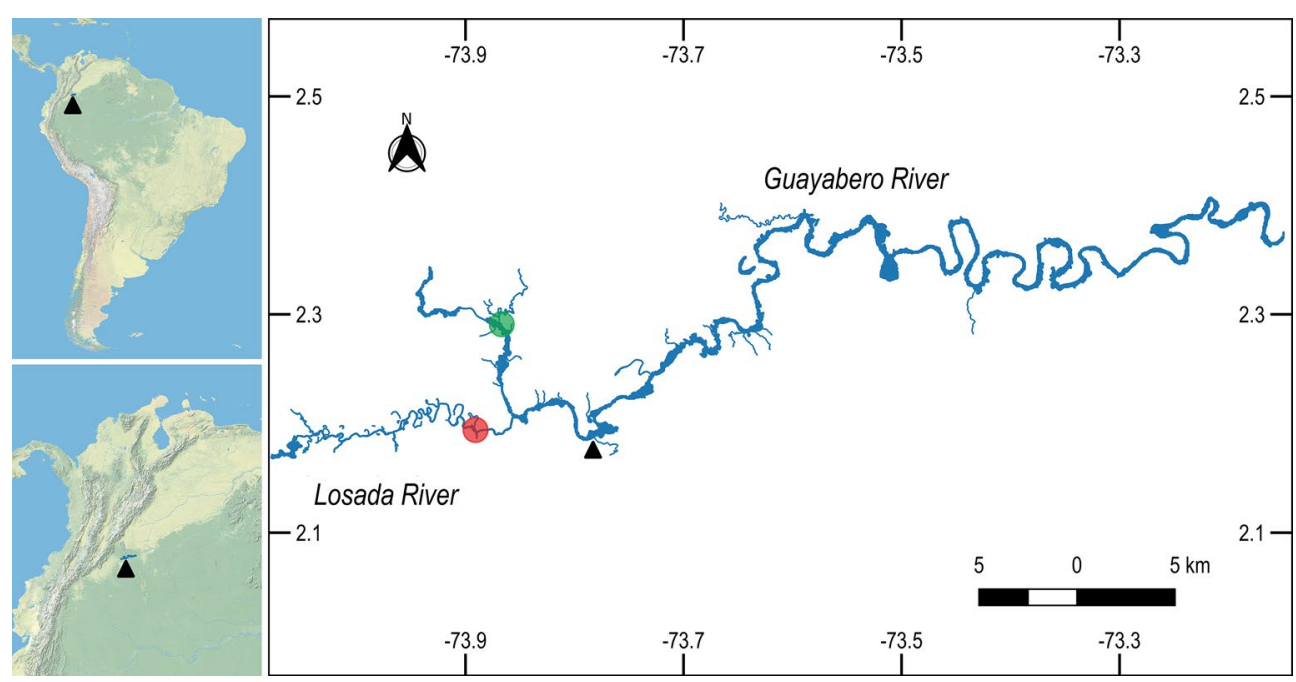

Fig. 7 Localization of study area and release sites. Triangle: La Macarena municipality, red dot: release site in Losada River, green dot: release site in Guayabero River

Table 3 Crocodile identification, sex, age, body length, weight, and geographic location at release site

\begin{tabular}{llllcl}
\hline Crocodile & Sex & Age (years) & Total length $(\mathbf{c m})$ & Weight $\mathbf{( K g )}$ & Release site location \\
\hline Fem_G & Female & 6 & 246 & 64 & Guayabero River \\
Male_G & Male & 10 & 312 & 111 & $2.288572^{\circ} \mathrm{N},-73.867053^{\circ} \mathrm{W}$ \\
Fem_L & Female & 7 & 235 & 59 & Losada River \\
Male_L & Male & 10 & 290 & 150 & $2.195056^{\circ} \mathrm{N},-73.891689^{\circ} \mathrm{W}$ \\
\hline
\end{tabular}

\section{Methods}

\section{Study area}

We conducted the study in the Guayabero and Losada Rivers in La Macarena municipality, department of Meta, Colombia (latitude $2.18^{\circ} \mathrm{N}, 73.78^{\circ} \mathrm{W}$ ) (Fig. 7). The region comprised lowland moist tropical forest between the Eastern Andes and the La Macarena Serranía with a very wet climatic unit [39], characterized by a mean annual temperature of $25.9{ }^{\circ} \mathrm{C}\left(\max 33.6{ }^{\circ} \mathrm{C}, \min 19{ }^{\circ} \mathrm{C}\right)$ and an annual mean precipitation of $2587 \mathrm{~mm}$. The Guayabero and Losada Rivers originate in the Eastern Andes and belong to the Duda-Guayabero drainage which eventually flows into the Orinoco River on the eastern Colombia/Venezuelan border. Both rivers are classified as white water rivers with high sediment and high productivity compared to the black or clear water rivers of the eastern Orinoco drainage [40]. The study area belongs to a recently defined priority habitats/crocodile conservation unit for the Orinoco crocodile [41].

Captive-reared crocodiles were released with Sirtrack ${ }^{\circledR}$ KiwiSat 202 Argos transmitters attached in their nuchal rosette [42]. The transmitters were duty cycled $3 \mathrm{~h}$ ON/1 h OFF every day, to provide maximum battery life while still maintaining adequate location information for this study. Veterinary procedures to attach the transmitters on the crocodiles were performed by a veterinarian from the Faculty of Veterinary Medicine and Zootechnics at the Universidad Nacional de Colombia. The animals were released in November 2015 at the Guayabero and Losada Rivers [8] (Table 3).

Geographic position, date, and time were provided by the Argos CLS. Argos provides a series of location probabilities known as location classes (LC) which are defined as follows: locations with precision $<250 \mathrm{~m}$ (LC3), locations with precision between $250 \mathrm{~m}$ and $500 \mathrm{~m}$ (LC2), locations with precision between $500 \mathrm{~m}$ and $1500 \mathrm{~m}$ (LC1), and locations with precision $>1500 \mathrm{~m}$ (LC0). Unknown accuracy locations are denoted as classes LCB or LCA [43].

To analyze movements and home range patterns, we used only locations with the highest precision (LC3). Because the hydrological dynamics in the study area are driven by the amount of precipitation, we used the precipitation data from the La Macarena climatic station [39] to break down the dataset according to two seasons as follows: a wet season with precipitation of $1828 \mathrm{~mm}$ 
between April and September and a dry season with precipitation of $759 \mathrm{~mm}$ occurring from October to March. Seasons were defined based on historical multiannual data of precipitation from mentioned climatic station [39], dry season corresponded to the months with a precipitation less than the multiannual average, whereas months with a precipitation greater than multiannual average corresponded to wet season.

To characterize the movement patterns, we calculated the total distance travelled per season (TD) as the sum of all step distances during the season. Distance from the release (RD) location was calculated as the farthest straight-line distance reached from the release site during each season. We also calculated the mean step length (MST) through dividing the cumulative travelled distance by the number of tracked days.

To quantify and describe the spatial patterns, we estimated the home range of each crocodile using the Kernel Home Range Estimate (KHRE) kernel use distribution (KUD) estimator [44] using the tool ZoaTrack. The smoothing parameter $h$ was estimated using a least squares cross-validation in a grid of $250 \mathrm{~m}$. [45]. We used this estimation to produce better estimates of home-range size and identify discrete patches of high use than other methods under data not very tight clumped, and additionally avoids potentially subjective choices of smoothing parameters [46]. We calculated the $95 \%$ and $50 \%$, utilization distributions, to evaluate home range and the core areas [13]. Home range map design and area calculations were performed in the GIS software QGIS 3.4.4 [47].

To determine activity patterns, we used data information from LC1 to LC3 locations because time of each location uplink was more important than the quality of the positions. Argos satellite coverage enables 6 to 7 passes per day at the equator, and these passes occur at fixed local solar times, thus the satellites can pick up the information from transmitters at least every $4 \mathrm{~h}$. Therefore, we could gather data information for each period when the transmitters were on and if the crocodiles were at the surface with the antenna exposed. We used the number of locations per transmitter-on periods as a proxy for time that crocodiles were above the surface of the water. Time spent above water is an approach already used in other crocodile studies [13] to describe activities such as time engaged in thermoregulation, time resting on land, time seeking terrestrial prey, and intraspecific interactions. In order to describe seasonal activities, we calculated the monthly average of locations per crocodile for each season. And to describe daily activities, we broke down the location data into time intervals of $3 \mathrm{~h}$ (20:00-22:59, 00:00-2:59, 8:00-10:59 and 12:00-14:59).
To explore the relationships among precipitation, crocodile size, age, movement, activity, and home range, we performed Spearman's correlation tests. To detect associations of the movements (except MST) and home range estimators between the sexes across seasons, we used a Chi square test on each pair of crocodiles and each subsequent season. To explore differences in movement and activity (number of locations per month) estimators among crocodiles, between sexes and seasons we used the Kruskal-Wallis test and Mann-Whitney pairwise comparison tests. Differences in activity among time intervals throughout the day were tested with the Friedman test using crocodiles as subjects and frequency of locations at each interval as treatments. To detect specific differences among intervals, we used the Wilcoxon pairwise comparison test.

\section{Abbreviations \\ UICN: International Union for Conservation of Nature; Fem_G: Female crocodile released in Guayabero River; Male_G: Male crocodile released in Guayabero River; Fem_L: Female crocodile released in Losada River; Male_L: Male crocodile released in Losada River; LC3: Locations with precision $<250$ m; LC2: Locations with precision between 250 and 500 m; LC1: Locations with precision between 500 and 1500 m; LCO: Locations with precision > 1500 m; LCA: Inaccurate locations; LCB: Inaccurate locations; TD: Travelled distance; RD: Distance from release; MST: Mean step length; KHER: Kernel Home Range Estimate.}

\section{Acknowledgements}

Released Project and tracking between November 2015 and September 2016 was funded by the agreements between The National University of Colombia with and The Environmental and Sustainable Development Ministry (38 de 2012) and The Corporation for the Sustainable Development to the Area of Special Management La Macarena (P.GDE.1.4.7.1.12.016). Satellite tracking between October 2016 and December 2017 was funded by Meta University Corporation under project "Ecology of Orinoco crocodile: implementing actions to its conservation in Colombia". We thank the Instituto Alexander von Humboldt - IAvH for support in re-charging PPT. Thanks to Wildlife Conservation Society Colombia for the media documenting of release. Special thanks to The Colombian Aerial Force and The Civil Defense-La Macarena which performed, respectively, the air and fluvial transportation of crocodiles. We thank Carlos A. Moreno-Torres who led all procedures to install transmitters on crocodiles, to EBTRF team (especially to Willington Martínez, Robinson Suárez, Pilar Vanegas, Esneider Castro and Felipe Parra) by its support in the manipulation, transportation and releasing of crocodiles. We thank Thomas R. Defler and Scott Eckert for helping us with the English review and editing.

\section{Authors' contributions}

Conceptualization: RMA MCAR. Data curation: RMA. Formal analysis: RAM. Funding acquisition: RMA MCAR. Investigation: RMA MCAR. Methodology: RMA. Project administration: RMA MCAR, Resources: RMA MCAR. Supervision: MCAR. Visualization: RMA. Writing—original draft: RMA MCAR. Writing-review and editing: RMA. All authors read and approved the final manuscript.

\section{Funding}

We state that sources of funding for research were:

1. The project "Ecology of the Orinoco crocodile: implementing actions for its conservation in Colombia"Resolution 159 - 2017 of Corporación Universitaria del Meta - UNIMETA.

2. The agreement P.GDE.1.4.7.1.12.016 signed between The National University of Colombia and The Corporation for the Sustainable Development to the Area of Special Management La Macarena

3. The agreements No. 38 - 2012 signed between The National University of Colombia and The Environmental and Sustainable Development Ministry. 
We also state that funders had no role in study design, data collection and analysis, decision to publish, or preparation of the manuscript.

\section{Availability of data and materials}

We state that all data will be fully available without restriction after article acceptance in https://zoatrack.org/projects/635.

\section{Ethics approval and consent to participate}

We state that all veterinary procedures to install the transmitters on crocodiles were approved by the Bioethical Committee of the Faculty of Veterinary Medicine and Zootechnics from "Universidad Nacional de Colombia", and these procedures were performed by a Carlos A. Moreno-Torres DVM from the same faculty.

\section{Consent for publication}

We state that all authors agree with the contents of the manuscript and its submission to the journal.

\section{Competing interests}

The authors declare that they have no competing interests.

\section{Author details}

${ }^{1}$ Dirección de investigaciones, Corporación Universitaria del Meta, Villavicencio, Colombia. ${ }^{2}$ Instituto de Ciencias Naturales- Estación de Biología Tropical Roberto Franco, Universidad Nacional de Colombia, Bogotá D. C, Colombia.

Received: 29 August 2019 Accepted: 2 May 2020

Published online: 18 May 2020

\section{References}

1. Medem F. Los Crocodylia de Colombia. 7, editor. Bogotá D.C: Colciencias; 1981.

2. Balaguera-Reina SA, Espinosa-Blanco A, Antelo R, Morales-Betancourt M, Seijas A. Crocodylus intermedius. The IUCN red list of threatened species 2018 [Internet]; 2018. https://www.iucnredlist.org/species/5661/3044743. Accessed 17 July 2019.

3. Morales-Betancourt MA, Lasso CA, Martínez-Barreto W, Ardila-Robayo MC, Bloor P. Caimán Ilanero. In: Morales-Betancourt MA, Lasso CA, Páez VP, Bock BC, editors. Libr Rojo Reptil Colomb. 1st ed. Bogotá D.C: JAVEGRAF; 2015. p. 258.

4. Merchán M, Castro A, Cárdenas M, Antelo A, Gómez F. Historia Natural y Conservacion del Caimán Llanero (Crocodylus intermedius) en Colombia. 1st ed. Madrid: Publiequipo; 2012.

5. Parra-Torres MF. Evaluación de la abundancia y el hábitat de Crocodylus intermedius y otros crocodilianos en el río Bita (Vichada, Colombia). Universidad Nacional de Colombia; 2017.

6. Antelo R. Biología del cocodrilo o caimán del Orinoco (Crocodylus intermedius) en la Estación Biológica El Frío, Estado Apure (Venezuela). [Madrid]: Universidad Autónoma de Madrid; 2008.

7. del Muñoz MC, Thorbjarnarson J. Movement of captive-released orinoco crocodiles (Crocodylus intermedius) in the Capanaparo River, Venezuela. J Herpetol. 2000;34:397.

8. Moreno-Arias RA, Ardila Robayo M, Martínez-Barreto W, Suárez-Daza R. Navigating with the Orinoco crocodile. Crocodile Spec Gr Newlett. 2016;35:14-5.

9. Thomas B. An application of a satellite tracking technologies to conserve wildlife: a case study approach. Palmerston North: Massey University; 2010.

10. Balaguera-Reina SA, Venegas-Anaya M, Sánchez A, Arbelaez I, Lessios HA, Densmore LD. Spatial ecology of the American crocodile in a tropical pacific island in Central America. PLOS ONE. 2016;11:1-20.

11. Fujisaki I, Hart KM, Mazzotti FJ, Cherkiss MS, Sartain AR, Jeffery BM, et al. Home range and movements of American alligators (Alligator mississippiensis) in an estuary habitat. Anim Biotelem. 2014;2:1-10.

12. Campbell HA, Dwyer RG, Irwin TR, Franklin CE. Home range utilisation and long-range movement of estuarine crocodiles during the breeding and nesting season. PLoS ONE. 2013:8:1-9.
13. Evans LJ, Davies AB, Goossens B, Asner GP. Riparian vegetation structure and the hunting behavior of adult estuarine crocodiles. PLOS ONE. 2017:12:1-12.

14. Fletcher R, Fortin MJ. Spatial ecology and conservation modeling: applications with R. Spat Ecol Conserv Model Appl with R; 2019, p. 1-523.

15. Kelly M, Silver S. The suitability of the jaguar (Panthera onca) for reintroduction. In: Hayward MW, Somers MJ, editors. Reintroduction of toporder predators. Chichester: Blackwell Publishing Ltd; 2009. p. 480.

16. Buderman FE, Hooten MB, Ivan JS, Shenk TM. Large-scale movement behavior in a reintroduced predator population. Ecography (Cop). 2018;41:126-39.

17. MMA, IAvH, UNAL. Programa Nacional para la Conservación del Caimán Llanero. 1st ed. Bogotá D.C: Unión Gráfica LTDA; 2002.

18. Antelo R. First Orinoco crocodile reintroduction in Colombia. Crocodile Spec Gr Newlett. 2015;34:18-9.

19. Lugo M. Avance en la investigación del estatus del caimán del Orinoco. Crocodile Spec Gr Newlett. 1996;15:14-6.

20. Barahona-Buitrago SL, Bonilla-Centeno OP. Evaluación poblacional de Caimán Llanero (Crocodylus intermedius) en un subareal de distribución en el departamento de Arauca (Colombia). Rev la Acad Colomb Ciencias. 1999;23:445-51.

21. Ardila-Robayo MC, Barahona-Buitrago SL, Bonilla-Centeno OP, Clavijo J. Actualización del status poblacional del Caimán Llanero (Crocodylus intermedius) en el Departamento de Arauca (Colombia). Memorias del Taller para la Conserv del Caimán del Orinoco (Crocodylus intermedius) en Colomb y Venez. Caracas; 2001.

22. Ardila-Robayo MC, Barahona-Buitrago SL, Bonilla-Centeno OP. Monitoreo poblacional de Crocodylus intermedius (caimán llanero) en los ríos Guayabero y Duda - Informe Final. Bogotá D.C; 2002

23. Read MA, Grigg GC, Irwin SR, Shanahan D, Franklin CE. Satellite tracking reveals long distance coastal travel and homing by translocated estuarine crocodiles, Crocodylus porosus. PLOS ONE. 2007;2:1-5.

24. Fukuda Y, Webb G, Manolis C, Lindner G, Banks S. Translocation, genetic structure and homing ability confirm geographic barriers disrupt saltwater crocodile movement and dispersal. PLOS ONE. 2019;14:1-20.

25. Seijas AE, Espinosa-Blanco AS, Ávila-Manjón P, Mendoza JM. Movement of juveniles orinoco crocodiles (Crocodylus intermedius) in the Cojedes river system, Venezuela. Crocodiles Proc 20th Work Meet Crocodile Spec Group, IUCN. 2010;176.

26. Grigg GC, Kirshner D. Biology and evolution of crocodylians. New York: Cornell University Press; 2015.

27. Kay WR. Movements and home ranges of radio-tracked Crocodylus porosus in the Cambridge Gulf region of Western Australia. Wildl Res. 2004;31:495.

28. Tucker AD, Limpus CJ, McCallum HI, McDonald KR. Movements and home ranges of Crocodylus johnstoni in the Lynd River, Queensland. Wildl Res. 1997;24:379-96.

29. Kernohan BJ, Gitzen RA, Millspaugh JJ. Analysis of animal space use and movements. Radiotracking Anim Popul Acad. San Diego: Academic; 2001. p. 125-166.

30. Joanen T, Mcnease L. A telemetric study of nesting female alligators on Rockefeller Refuge, Louisiana. Proc Annu Conf Southeast Assoc Game Fish Comm. 1970:24:175-93.

31. Goodwin TM, Marion WR. Seasonal activity ranges and habitat preferences of adult alligators in a north-central Florida lake. J Herpetol. 1979;13:157-63.

32. Rootes WL, Chabreck RH. Reproductive status and movement of adult female alligators. J Herpetol. 1993;27:121-6.

33. Thorbjarnarson JB, Hernández G. Recent investigations of the status and distribution of the Orinoco crocodile Crocodylus intermedius in Venezuela. Biol Conserv. 1992;62:179-88.

34. Calverley PM, Downs CT. Movement and home range of nile crocodiles in Ndumo Game Reserve. South Africa. Koedoe. 2015;57:1-13.

35. Ayarzagüena J. Ecologia del caiman de anteojos o baba (Caiman crocodilus L.) en los Ilanos de Apure (Venezuela). Doñana Acta Vertebr. 1983:10:7-136

36. Seebacher F, Grigg GC. Patterns of body temperature in wild freshwater crocodiles, Crocodylus johnstoni: thermoregulation versus thermoconformity, seasonal acclimatization, and the effect of social interactions. Copeia. 2006;1997:549. 
37. Ayarzagüena J, Castroviejo J. Las babas (Caiman crocodilus L.) de la Estación Biológica EL Frío (Estado de Apure), Llanos del Orinoco, Venezuela. Contrib al Conoc los caimanes del género Caiman Suramérica. Madrid; 2008. p. 181-294.

38. Loveridge JP. Thermoregulation of the nile crocodile Crocodylus niloticus. Symp Zool Soc London. 1984;52:443-67.

39. Minorta-Cely V, Rangel-Ch JO. El clima de la Orinoquia colombiana. Colomb Divers Biótica XIV La Región La Orinoquia Colomb. 1st ed. Bogotá D.C: Universidad Nacional de Colombia; 2014. p. 153-206.

40. Machado-Allison A, Lasso CA, Usma JS, Sánchez-Duarte P, Lasso-Alcalá O. Peces. Biodivers la cuenca del Orinoco Bases científicas para la identificación áreas prioritarias para la Conserv y uso Sosten la Biodivers. 1st ed. Bogotá D.C: Unión Gráfica LTDA; 2010. p. 216-57.

41. Balaguera-Reina SA, Espinosa-Blanco AS, Morales-Betancourt MA, Seijas $A E$, Lasso CA, Antelo R, et al. Conservation status and regional habitat priorities for the Orinoco crocodile: past, present, and future. PLOS ONE. 2017;12:1-20.

42. Brien M, Webb G, Manolis C, Ottaway D. A method for attaching tracking devices to crocodilians. Herpetol Rev. 2010;41:305-8.

43. ARGOS. Argos User's Manual [Internet]; 2016. http://www.argos-syste m.org/manual/. Accessed 15 June 2016.
44. Worton BJ. Kernel methods for estimating the utilization distribution in home-range studies. Ecology. 1989;70:164-8.

45. Dwyer RG, Brooking C, Brimblecombe W, Campbell HA, Hunter J, Watts M et al. An open Web-based system for the analysis and sharing of animal tracking data. Anim Biotelem. 2015;3:1-11.

46. Gitzen RA, Millspaugh JJ, Kernohan BJ. Bandwidth selection for fixedkernel analysis of animal utilization distributions. J Wildl Manage. 2006;70:1334-44.

47. QGIS Development Team. QGIS Geographic Information System. Open Source Geospatial Foundation Project [Internet]; 2018. http://qgis.osgeo .org.

\section{Publisher's Note}

Springer Nature remains neutral with regard to jurisdictional claims in published maps and institutional affiliations.
Ready to submit your research? Choose BMC and benefit from:

- fast, convenient online submission

- thorough peer review by experienced researchers in your field

- rapid publication on acceptance

- support for research data, including large and complex data types

- gold Open Access which fosters wider collaboration and increased citations

- maximum visibility for your research: over $100 \mathrm{M}$ website views per year

At BMC, research is always in progress.

Learn more biomedcentral.com/submissions 